\title{
Peningkatan Pengetahuan Penggunaan Alat Pelindung Diri (APD) di Bengkel Wilayah Banguntapan, Bantul, Yogyakarta
}

\author{
Julian Dwi Saptadi1, Pipit Nurunnisail Khotimah2, Lalu Aditya Arya Ninggrat3, Ardarina Delfiona Kekasi4, \\ Marissa Alvionita5, Nadia Arzelina6, Layla Nur Chuzaemah7 \\ Fakultas Kesehatan Masyarakat, Universitas Ahmad Dahlan, ${ }^{2,3}$ \\ e-mail: julian.saptadi@ikm.uad.ac.id
}

\begin{abstract}
ABSTRAK
Kurangnya kesadaran dan pengetahuan akan pentingnya perilaku K3 pada pekerja bengkel dapat menimbulkan terjadinya kecelakaan kerja. Maka dari itu, perlu adanya edukasi untuk meningkatkan pengetahuan pentingnya penggunaan Alat Pelindung Diri (APD) pada saat bekerja agar dapat mengurangi angka kecelakaan kerja dan penyakit akibat kerja. Tujuan: Tujuan dari kegiatan ini adalah memberikan edukasi untuk meningkatkan kesadaran dan pengetahuan para pekerja bengkel tentang penggunaan Alat Pelindung Diri (APD). Metode: Metode yang digunakan adalah dengan ceramah dan menggunakan poster dan leaflet tentang Alat Perlindungan Diri (APD). Hasil: masih adanya beberapa masalah yang terdapat di bengkel yaitu kurangnya pengetahuan karyawan tentang pentingnya penggunaan Alat Pelindung Diri (APD) yang kurang lengkap di lingkungan kerja yang tidak aman Dampak: Dampak yang diperoleh dari kegiatan pengabdian ini yaitu para pekerja bengkel lebih memahami bahaya dan risiko ketika mereka tidak menggunaan APD dan lingkungan kerjanya tidak aman, selain itu pemberian poster dan leaflet juga menambah pengetahuan bagi para pekerja bengkel.
\end{abstract}

Kata kunci: Perilaku Keselamatan dan Kesehatan Kerja, Alat Perlindungan Diri, Penyakit Akibat Kerja,

\section{ABSTRACT}

Lack of awareness and knowledge of the importance of OSH behavior in workshop workers can lead to work accidents. Therefore, education is needed to increase the knowledge of the importance of using Personal Protective Equipment (PPE) at work in order to reduce the number of work accidents and occupational diseases. Purpose: The purpose of this activity is to provide education to increase the awareness and knowledge of workshop workers about the use of Personal Protective Equipment (PPE). Method: The method used is lectures and uses posters and leaflets about Personal Protection Equipment (PPE). Result: there are still some problems found in the workshop, namely the lack of employee knowledge about the importance of using incomplete personal protective equipment (PPE) in an unsafe work environment. Impact: The impact of this service is that the workshop workers better understand the dangers and risks when they do not use PPE and the work environment is not safe, besides providing posters and leaflets also increase knowledge for workshop workers.

Keywords: Health amd Safety Behavior, Personal Protective Equipment, Occupational Disease

\section{PENDAHULUAN}

Perkembangan industri di Indonesia semakin maju. Perkembangan itu belum di imbangi dengan kesadaran dan perilaku para pekerja untuk memahami dan melaksanakan keselamatan kerja secara baik dan benar (Sucipto, 2014). Perilaku keselamatan merupakan sikap dalam organisasi dan personal yang menekankan pentingnya keselamatan. Perilaku keselamatan menentukan agar semua kewajiban yang berkaitan dengan keselamatan harus dilaksanakan secara benar, seksama, dan penuh rasa tanggung jawab (Mallapiang et al., 2018).

Menurut laporan Internasional Labour Organization (ILO) mengungkapkan bahwa setiap tahun terjadi 2,2 juta kematian yang disebabkan karena penyakit atau kecelakaan akibat kerja. Di Indonesia, Badan Penyelenggara Jaminan Sosial (BPJS) Ketenagakerjaan mencatat, pada tahun 2017 angka kecelakaan kerja yang dilaporkan mencapai 123.041 kasus, sementara sepanjang 2018 mencapai 173.105 kasus (Ahmad, 2012). Ada dua golongan yang menyebabkan terjadinya kecelakaan kerja. Golongan pertama adalah faktor mekanis dan lingkungan (unsafe condition), dan golongan kedua adalah faktor manusia (unsafe action). Faktor manusia tersebut dilatar belakangi oleh berbagai faktor seperti pengetahuan, keinginan, minat, emosi, kehendak, berpikir, motivasi, persepsi, sikap, dan reaksi. Dari 
faktor-faktor tersebut yang dapat membentuk dan mempengaruhi perilaku K3 dari seorang pekerja (Suyono \& Nawawinetu, 2013).

Pengetahuan dalam penggunaan Alat Pelindung Diri (APD) pada saat bekerja merupakan suatu keharusan bagi pekerja dalam melakukan pekerjaan demi menjaga kesehatan dan keselamatan kerja. Seperti halnya sikap merupakan reaksi atau respon yang masih tertutup dari seseorang terhadap suatu stimulus atau objek, sikap penggunaan APD yang kurang baik kemungkinan disebabkan oleh beberapa faktor lain seperti tingkat pengetahuan, apabila pekerja tidak mengetahui tentang APD dapat berpengaruh terhadap perubahan sikap (Ahmad, 2012)

Berdasarkan hasil observasi yang dilakukan pada bengkel yang berada di wilayah Puskesmas Banguntapan III, ditemukan beberapa masalah terkait dengan kurangnya penerapan perilaku keselamatan dan kesehatan kerja seperti tidak menggunakan Alat Pelindung Diri (APD) saat bekerja di lingkungan kerja yang tidak aman sehingga menimbulkan kecelakaan kerja yang ditemukan. Berbagai masalah yang ditemukan di bengkel-bengkel tersebut dapat meningkatkan potensi bahaya bagi para perja. Jika masalah tersebut tidak segera ditangani maka hal itu dapat menjadi masalah besar yang dapat membahayakan pekerja dan dapat menyebabkan kecelakaan kerja.

Dilihat dari permasalahan yang terjadi di bengkel, terdapat beberapa akibat dari tidak menggunakan Alat Pelindung Diri (APD) seperti terkilir, tergores, terjatuh alat kerja. Oleh karena itu, salah satu cara yang efektif untuk mengurangi jumlah kecelakaan kerja dan penyakit akibat kerja di bengkel yaitu dengan menyadarkan para pekerja untuk memperhatikan kesehatan dan keselamatan dirinya. Salah satu cara untuk menyadarkan para pekerja adalah dengan adanya edukasi yang harus dilakukan untuk mengurangi risiko kecelakaan kerja mengenai pentingnya penggunaan Alat Pelindung Diri (APD) di tempat kerja ataupun menggunakan cara lain yang mudah diterapkan di bengkel untuk mengurangi risiko terjadinya kecelakaan kerja di tempat kerja

\section{METODE}

Metode yang diterapkan dalam program kegiatan pengabdian masyarakat ini adalah dengan menggunakan ceramah dan poster. Poster yang diberikan tentang Alat Perlindungan Diri (APD terkait dengan perilaku K3. Kami juga menjelaskan isi dari media yang diberikan secara singkat kepada para pekerja, dengan tujuan agar para pekerja lebih memahami isinya. Kegiatan pemberian poster dilaksanakan pada hari Sabtu pukul 10.00-14.00 WIB. Kegiatan pemberian poster dilakukan dalam waktu satu hari karena tidak membutuhkan waktu yang lama. Kegiatan ini dilakukan Bersama dengan 6 mahasiswa Fakultas Kesehatan Masyarakat (FKM). Sasaran dalam kegiatan pengabdian ini adalah para pekerja bengkel yang berada di wilayah PuskesmasBanguntapan III.

\section{HASIL DAN PEMBAHASAN}

Hasil dari pengabdian ini yaitu ditemukan beberapa masalah yang terdapat di bengkel yaitu penggunaan Alat Pelindung Diri (APD) yang kurang lengkap. Penggunaan APD yang kurang lengkap kami temukan di semua bengkel yang kami amati. Permasalahan tersebut kegiatan pengabdian ini dilakukan dengan memberikan ceramah dan poster. 


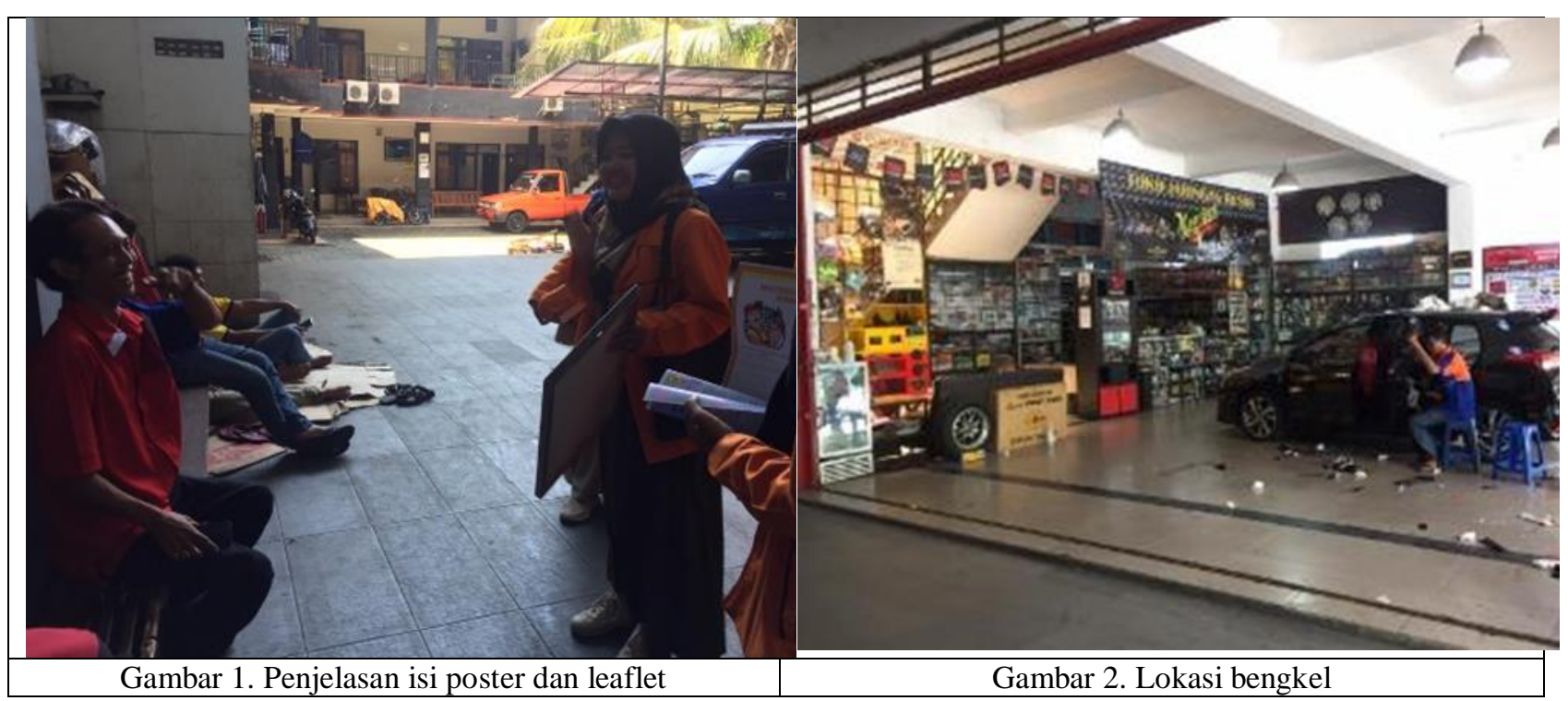

Poster yang kami berikan berupa penggunaan APD yang lengkap, ajakan membudayakan perilaku 5R (Ringkas, Rapi, Resik, Rawat, Rajin). Dalam melakukan pengabdian ini kami memberikan poster tersebut kepada pihak bengkel dan meminta untuk ditempelkan di dinding bengkel, agar poster tersebut dapat dilihat dengan mudah, dapat dibaca kapan saja, dan mudah diingat oleh para pekerja..

Penggunaan Alat Pelindung Diri (APD) merupakan tahap akhir dari metode pengendalian kecelakaan ataupun penyakit akibat kerja. Namun, penggunaan APD akan menjadi sangat penting apabila pengendalian secara teknis dan administrative telah dilakukan secara maksimal tetapi potensi risiko masih tergolong tinggi (Raodhah \& Gemely, 2014). Besarnya manfaat dari penggunaan Alat Pelindung Diri (APD) tidak menjamin semua pekerja di bengkel untuk menggunakannya. Banyak faktor yang mempengaruhi perilaku pekerja sehingga tidak menggunakan alat pelindung diri. Faktor tersebut seperti pemilik bengkel tidak menyediakan alat pelindung diri yang lengkap dan pekerja bengkel merasa kurang nyaman dengan penggunaan APD.

Poster tentang budaya 5R (Ringkas, Rapi, Resik, Rawat, Rajin) kami berikan karena melihat kondisi lingkungan yang tidak aman. Banyak alat kerja yang tidak sesuai dengan tempatnya. Menurut Bhastary \& Suwardi (2018) lingkungan kerja (the work environment) adalah sumber daya dan situasi yang dibutuhkan oleh seseorang untuk melakukan pekerjaan. Tempat atau lingkungan kerja akan mempengaruhi terhadap pekerjaan pekerja. Lingkungan kerja yang buruk akan menyebabkan karyawan merasa terganggu dalam pekerjaannya dan akan menyebabkan turunnya kinerja pegawai. Selain itu lingkungan kerja yang tidak aman juga beresiko terhadap terjadinya kecelakaan kerja.

Kegiatan pengabdian yang dilakukan telah berjalan dengan baik dan lancar. Sasaran pengabdian yaitu para pekerja bengkel, mereka menunjukkan respon yang baik terhadap kegiatan atau program yang telah dilaksanakan. Dalam pelaksanaan kegiatan pemberian ceramah dan poster para pekerja terlihat memberikan respon yang positif, mereka terlihat menyimak penjelasan yang kami berikan dan sangat antusias.

Dampak yang diperoleh dari kegiatan pengabdian ini yaitu para pekerja bengkel lebih memahami bahaya dan risiko ketika mereka tidak menggunaan APD dan lingkungan kerjanya tidak aman. Selain itu poster juga menambah wawasan bagi mereka khususnya dalam penggunaan Alat Pelindung Diri dan Budaya 5R (Ringkas, Rapi, Resik, Rawat, Rajin) dalam bekerja di bengkel agar mengurangi risiko terjadinya kecelakaan kerja. Dengan memberikan poster di harapkan agar pekerja bengkel dapat bekerja secara aman dengan menggunakan alat perlindungan diri (APD) serta bekerja sesuai dengan standarnya. Dan pekerja dapat menjaga lingkungan kerja di bengkel secara bersih dan rapi agar tidak menyebabkan kecelakaan kerja yang bisa di sebabkan oleh hal sepele seperti alat bengkel yang berserakan di lantai maupun tetesan oli. Selain itu dengan diberikannya poster dan leaflet ini dapat 
meningkatkan derajat kesehatan para pekerja bengkel dan terhindarnya para pekerja dari kecelakaan kerja.

\section{SIMPULAN}

Berdasarkan hasil dari kegiatan pengabdian ini, dapat disimpulkan bahwa para pekerja bengkel mengetahui bagaimana situasi atau keadaan lingkungan bengkel yang aman serta lingkungan bengkel yang sehat agar para pekerja terhindar dari penyakit yang ditimbulkan dari lingkungan kerja. Para pekerja juga sadar akan pentingnya penggunaan APD sehingga saat bekerja terlindungi dan terhindar dari bahaya maupun risiko kecelakaan kerja. Serta kesadaran pekerja tentang pentingnya bekerja dengan prinsip 5R (Ringkas, Rapi, Resik, Rawat, Rajin) karena bekerja dengan prinsip 5R akan membuat para pekerja aman serta risiko kecelakaan kerja makin kecil.

\section{DAFTAR REFERENSI}

Ahmad, R. (2012). Hubungan Pengetahuan dan Sikap Karyawan dengan Penggunaan Alat Pelindung Diri (APD) pada PT HARTA SAMUDRA Pelabuhan Perikanan Nusantara Ambon. Jurnal Keselamtan dan Kesehatan Kerja. 2011, 5.

Bhastary, M. D., \& Suwardi, K. (2018). Analisis Pengaruh Keselamatan Dan Kesehatan Kerja (K3) Dan Lingkungan Kerja Terhadap Kinerja Karyawan Di Pt.Samudera Perdana. Jurnal Manajemen Dan Keuangan, 7(1), 47-60. https://doi.org/10.33059/jmk.v7i1.753

Hidayat, N., \& Wahyuni, I. (2016). Kajian Keselamatan Dan Kesehatan Kerja Bengkel. Jurnal Pendidikan, Teknologi Dan Kejuruan, 23, 51-66.

Mallapiang, F., Amansyah, M., \& Thaha, A. I. (2018). Gambaran Kecelakaan Kerja, Penyakit Akibat Kerja Dan Postur Janggal Pada Pekerja Armada Mobil Sampah Tangkasaki' Di Kota Makassar. Public Health, 10, 48-62.

Raodhah, S., \& Gemely, D. (2014). Faktor-Faktor Yang Berhubungan Dengan Penggunaan Alat Pelindung Diri Pada Karyawan Bagian Packer PT Semen Bosowa Maros Tahun 2014. Public Health Science Journal, VI(2), 437-449.

Sucipto, C.D. 2014. Keselamatan dan Kesehatan Kerja. Yogyakarta: Gosyen Publishing

Suyono, K. Z., \& Nawawinetu, E. D. (2013). Hubungan Antara Faktor Pembentuk Budaya Keselamatan Kerja Dengan Safety Behaviour di PT DOK dan Perkapalan Surabaya Unit Hull Construction. The Indonesian Journal of Occupational Safety and Health, 2(1), 67-74.

Syafada, F. (2013). Pola Kuman Dan Sensitivitas Antimikroba Pada Infeksi Saluran Kemih. Jurnal Farmasi Sains Dan Komunitas, 10(1), 9-13. https://doi.org/10.1001/archpediatrics.2011.1413 